\title{
The Relationship between Sustainable Internationalization Strategies and Qualification Alignments to National Qualification Framework
}

\author{
Esra Saleh AIDhaen \\ Department of Management and Marketing, College of Business and Finance, Ahlia University, Bahrain
}

Received September 12, 2020; Revised November 7, 2020; Accepted November 19, 2020

\section{Cite This Paper in the following Citation Styles}

(a): [1] Esra Saleh AlDhaen, "The Relationship between Sustainable Internationalization Strategies and Qualification Alignments to National Qualification Framework," Universal Journal of Educational Research, Vol. 8, No. 12A, pp. 7455 - 7460, 2020. DOI: 10.13189/ujer.2020.082529.

(b): Esra Saleh AlDhaen (2020). The Relationship between Sustainable Internationalization Strategies and Qualification Alignments to National Qualification Framework. Universal Journal of Educational Research, 8(12A), 7455 - 7460. DOI: 10.13189/ujer.2020.082529.

Copyright $\bigcirc 2020$ by authors, all rights reserved. Authors agree that this article remains permanently open access under the terms of the Creative Commons Attribution License 4.0 International License

\begin{abstract}
The Majority of Higher Education Institutes attracted international collaboration and affiliations as part of internationalization strategy. Upon hosting an academic programme, both universities must assure that the programmes are equivalent in standards, with mutual agreement upon the methodology of delivery. The purpose of this study is to share successful practices of universities that sustained hosting cross boarder academic programmes hosted by local universities with international award from the UK and USA at postgraduate level. The paper will share the method and the adapted framework to enable a long-term relationship between both HEIs, compliance with regulatory requirements, as well as addressing graduate attributes in line with both HEI's missions. This paper will also demonstrate challenges and advantages of alignment to local qualification framework to maintain the equivalency of standards that leads to a sustainable internationalization strategy. As a major conclusion, this paper will demonstrate strategic decisions that could be adapted by leaders of Higher Education Institutions, while considering International collaboration or activating an International agreement. We can analyse this by considering local regulatory requirements and alignment with National Qualification Framework as well as linking the policies and procedures to United Nations Sustainable Development Goals. The findings of this paper provide insights for leaders of Higher Education Institutions and regulators to align their frameworks and policies to support
\end{abstract}

Internationalization.

Keywords Higher Education Institutes (HEIs), National Qualification Framework (NQF), Association to Advance Collegiate Schools of Business (AACSB), Quacquarelli Symonds (QS), Bahrain Education and Training Quality Authority (BQA), Higher Education Council (HEC), Sustainable Development Goal (SDG)

\section{Introduction}

The higher Education Sector faces various demands by different stakeholders including employers, parents, students, regulatory and quality assurance agencies. According to Foskett, N. (2010) [11] Internationalization strategies are important to reflect and share practices between two Higher Education Institutions; internationalization strategies also allow diversity and other collaborative outcomes such as formal benchmarking and research. In similar context, Adel, H. M. et.al (2018) [2] shared a successful practice of UK university hosting a programme in Egypt and highlighted the importance of effective management of such an international agreement.

International Accreditation and ranking bodies are playing a vital role in promoting international strategies and international collaboration, for instance: Association to 
Advance Collegiate Schools of Business (AACSB) Business School International Accreditation supports Collaborative Provisions/Transfer Credit covering different types of collaborative provision (AACSB Standard 2020, pg. 14) [1]. Similarly, Quacquarelli Symonds (QS) world ranking includes internationalization as a ranking criterion and discusses Internationalization Strategy and its impact in various conferences (QS Maple 2020) [24].

Furthermore, United Nations promoted Quality of Educations as a Sustainable Development Goal (SDG 4), which includes collaboration with international education bodies through collaborative agreements such as hosting programme, dual qualifications.

In the Kingdom of Bahrain, there are well-established regulatory requirements set by Higher Education Council (HEC) for collaborative provision, which is used as a guideline for establishing a robust agreement. In terms of quality assurance of collaborative provision, Bahrain Education and Training Quality Authority (BQA) was established in 2008 as an independent body to review the quality of all academic programmes offered by Higher Education Institutes (HEIs) in Bahrain including cross boarder programmes. Furthermore, in 2012, National Qualification Framework (NQF) was established to be part of BQA; the framework is developed in line with international frameworks and clear validation standards (Aldhaen et.al 2018; Hornblow, D., et.al 2019) [3,14]. The purpose of the framework did not restrict spreading the culture of lifelong learning across all education providers in Kingdom of Bahrain including HEIs and validated the level of the learning outcomes of the qualifications offered in line with expected graduate attributes as classified by the labour market needs.

This paper will describe the importance of NQF in sustaining internationalization strategies by describing the process of NQF foreign qualification alignment to national qualification framework and demonstrate the adapted framework to enable long-term relationship between both HEIs, compliance with regulatory requirements, as well as addressing graduate attributes in line with both HEIs missions. This paper will also highlight challenges and advantages of alignment to local qualification framework to maintain equivalency of standards that leads to sustainable internationalization strategy.

\section{National Qualification Framework and Internationalization Regulations}

In the Kingdom of Bahrain, BQA aligned their strategy with United Nations SDG4 related to quality education, one of the main pillars towards quality education is a systematic programme review to assess the minimum requirements of quality assurance standards. Since 2008, BQA conducted two cycles of programme reviews covering Business, Information Technology, Medical, Engineering and Arts and Science fields. (BQA Annual Report 2019) [6]. International awarded degrees that are hosted programmes are also subjected to a rigorous and detailed quality programme review to quality assure its standards and highlight clear lines of accountability.

Upon successful outcome of programme reviews, all national qualifications are subjected to be placed on National Qualification Framework by conducting a thorough qualification placement process on the National Qualification Framework. In this context, various case studies were conducted to evaluate the impact of qualification framework on the quality of teaching and learning including interaction with learners and other related activities. According to (Tamronglak, A. 2020) [28] a study was conducted in Thailand and concluded that qualification framework promotes interactive teaching and learning, life-long learning skills and allows progression pathways. In addition, Shaukat, S. et.al (2020) [25] stated that teaching and learning in GCC countries requires an upgrade in terms of online teaching usage and therefore, a GCC qualification framework would support its consistency. This is in sync with Moldovan, L.'s (2020) [18] conclusion that referencing framework which includes internationally awarded degrees allows a continuous Improvement of Employability Assessment. The Arab Network for Quality Assurance Higher Education (ANQAHE) established networks in consultation with leaders of quality assurance agencies from Arab countries, which then establish Arab Qualification Framework (AQF) to support learners' progression between Arab Countries. Internationally. The framework was designed to fit with UK and USA qualification credits (Qualification Framework ANQAHE Model , 2012). Table 1 below provides comparison between qualification frameworks in GCC region and UK.

Table 1. Level Comparison of qualifications placed on Bahrain National Qualification Framework (related to Higher Education).

\begin{tabular}{|c|c|c|c|c|c|c|}
\hline & \multicolumn{4}{|c|}{ Gulf Countries } & \multicolumn{2}{c|}{ UK } \\
\hline $\begin{array}{c}\text { Degree } \\
\text { Level }\end{array}$ & $\begin{array}{c}\text { Bahrain National } \\
\text { Qualifications } \\
\text { Framework (NQF) } \\
*\end{array}$ & $\begin{array}{c}\text { Oman } \\
\text { Qualification } \\
\text { Framework (OQF) } \\
* *\end{array}$ & $\begin{array}{c}\text { KSA } \\
\text { Qualification } \\
\text { Framework } * * *\end{array}$ & $\begin{array}{c}\text { Qualification } \\
\text { Framework } \\
\text { Emirates } \\
(\mathrm{QFE}) * * * *\end{array}$ & $\begin{array}{c}\text { Scottish Credit } \\
\text { and } \\
\text { Qualifications } \\
\text { Framework } \\
\text { (SCQF) }\end{array}$ & $\begin{array}{c}\text { Frameworks for } \\
\text { Higher Education } \\
\text { Qualifications of UK } \\
\text { Degree-Awarding } \\
\text { Bodies (FHEQ) }\end{array}$ \\
\hline PhD & 10 & 10 & 6 & 10 & 12 & 8 \\
\hline Master's & 9 & 9 & 5 & 9 & 11 & 7 \\
\hline $\begin{array}{c}\text { Bachelor' } \\
\text { s Degree }\end{array}$ & 8 & 8 & 3 & 7 & 10 & 6 \\
\hline
\end{tabular}

*https://www.bqa.gov.bh//En/AboutQaaet/Pages/default.aspx

**http://www.oaaa.gov.om/Journal/Qualification\%20Arrangements.pdf

***:https://www.mu.edu.sa/sites/default/files/National\%20Qualifications\%20Framework\%20for\%20HE\%20in\%20KSA.pdf

**** https://www.nqa.gov.ae/EN/Pages/QFEmirates/QualificationsFramework/Handbook.aspx 
Table 2. Summary of definitions of collaborative provision

\begin{tabular}{|l|l|}
\hline Collaborative Provision Type & Explanation \\
\hline Joint Degree & $\begin{array}{l}\text { Joint Degree is a collaborative delivered programme, upon successful completion learners will } \\
\text { receive a single degree from both Universities and the name of HEIs will appear in the certificates } \\
\text { and transcripts. }\end{array}$ \\
\hline Dual/Double Degrees & $\begin{array}{l}\text { The dual/double degrees allow the learner to obtain a multiple degree from collaborative HEIs upon } \\
\text { successful completion }\end{array}$ \\
\hline Articulation or Twinning Agreement & $\begin{array}{l}\text { Articulation or Twinning Agreement, learners will be recognized/ accepted in other HEI having } \\
\text { completed courses in another HEI into its degree Programme. }\end{array}$ \\
\hline Franchise or Hosted Programme * & $\begin{array}{l}\text { Franchise or Hosted Programme collaborative provision is a programme developed by the mother } \\
\text { HEI and delivered with \% of collaborative organization. But the degree is awarded by the mother } \\
\text { HEI with adherence to collaborative organization regulatory requirements. }\end{array}$ \\
\hline
\end{tabular}

Higher Education Council in Kingdom of Bahrain set clear regulations for establishment of internationally awarded degrees; these rules allow HEIs to develop a sustainable agreement that allows effective implementation and long-term relationship (more information will be in section 3.1). International Accreditation bodies played a vital role in classifying the type of collaborative provision awarded degrees. Table 2 provides a summary of definitions of collaborative provision.

Table 1 created direct mapping and equivalency which supported validation of articulation or twinning agreement. Collaborative provision and transnational education was highlighted as a challenge by Ong, K. C., \& Chan, D. K. (2012) [22]. Similarly, Henderson, M., Barnett, R., \& Barrett, H. (2017) [13] highlighted that one on the major challenge of transnational education could be the teaching styles and delivery methods which could be supported by faculty professional development. Consequently, NQF was able to have a unified manner of delivery including a clearly classified notional hours and levels with expected outcomes. Table 1 described clearly the equivalency of qualification level that eased the process of mapping qualification and also provided a consistent internationally aligned method of delivery classified by notional hours against each formal and informal activity.

The following section will demonstrate the case study of Franchise related to the application of alignment to national qualification framework to a hosted programme; the application will highlight the important criteria to sustain internationalization strategies.

\section{Alignment to National Qualification Framework}

This section will provide a critical literature analysis of the four pillars to be considered while activating collaborative provision. The following sections will practice and challenges of foreign alignment.

\subsection{Admissions Requirements}

Admission requirements including programme specific criteria are important to ensure that the learners are supported with appropriate progression pathways during their learning. According to Mehrotra, (2020) [17] failing to consider admission criteria may impact on failure of implementation of the national qualification framework. This issue was a major challenge in India specifically for vocational and training institutes. Similarly, Oanda, I. (2020) [20] highlighted that in Africa, candidates may not appropriately select their educational field due to the lack of admission criteria that define clear pathways to learners, therefore emphasis transparent admission criteria were made. BQA ensure that all qualifications aligned to National Qualification Framework are supported with clearly defined admission criteria which is part of Programme Review Standards for "cross boarder qualifications” (Programme Review Framework Cycle 2). In this context, (Take, H., \& Shoraku, A. 2018) [29] highlighted that HEIs must consider all aspects while considering internationalization, one of which could be related to the context and regulatory requirements.

In the UK, admission requirements are supported by Recognition of Prior Learning (RPL), however Dunn, C. (2018) [9] stated that RPL could be based on life-long learning knowledge and experience followed by quality assured recognition. Dunn, C. (2018) [9] also highlighted that HEIs must consider the challenges involved in applying RPL and assure maintain learner progression while admitting a learner. In the Kingdom of Bahrain, RPL is yet recognized by the regulatory body, however BQA is promoting the concept to HEIs for future plans.

As a case study, this paper demonstrate a hosted $\mathrm{PhD}$ Programme offered by UK university, as a challenge faced that the awarding HEI considers RPL, however it is not recognized in Kingdom of Bahrain and restricted to formal learning only. Therefore, NQF alignment process verifies the adherence to the regulatory requirements which maintains active collaborative provision as well as assures long term sustainability.

\subsection{Academic Planning Framework (Resources Planning and Delivery)}

According to Jackson, N. (1997) [17] emphasized on the importance of regular interactions with leaders of the collaborative provision and regulatory channels to adhere to the internal and external regulatory requirements, and 
assure smooth activation of collaborative agreements. In similar context, (Take, H., \& Shoraku, A. 2018; Karagoz, S. 2018) [29; 16] stated that regulatory requirement must be critically evaluated specifically related to ownership, delivery and assessments. In order to support HEIs, UNESCO-OECD developed Guidelines for Quality Provision in Cross - border Higher Education that could be used to address this issue, which is also in line with SDG4.

Henderson, M., Barnett, R., \& Barrett, H. (2017) [13] stated that one of the main challenges that should be considered to sustain internationalization is that assurance of faculty professional development is to sustain equivalent teaching and delivery standards. Therefore, study investigated by Chalmers, D., \& Gardiner, D. (2015) [7] on the impact of faculty professional development was in relation to teaching and learning, the study concluded that professional development should be linked to the main target and consider faculty background and context.

According to Décamps, A., et.al (2017) [8], attaining collaborative provision relays on leader's initiatives and the HEI strategy, however sustaining it may be a challenge, therefore an academic planning framework is a major requirement to assure validated and effective means of implementation. In this context, BQA has a set a major requirement for cross boarder qualification and therefore all HEIs operating and internationally awarded degree must have a well-designed academic planning framework that describes the role of each entity, covering planning of resources including faculty, teaching materials and validation of assessments in terms of equivalency (Programme Review Framework Cycle 2; Wiek, A. et. al (2011) [31].

As a case study of this paper, a joint board was established that consists leaders and members from both HEIs and meets regularly in line with planned schedule. The committee looks into the operations that include approving an annual academic planning framework and strategic level decisions for sustainability. Table 3 provides a summary of the issues decisions and practices which include decisions related to faculty development, faculty allocation and assessment validity.

This paper demonstrate a hosted $\mathrm{PhD}$ Programme offered by UK and also a PG awarded degree by university from USA, as a challenge faced that the awarding HEI considers external moderation with specific criteria that are allocated by the awarded body. However, in line BQA programme review cycle, external moderation must be conducted systematically and regularly to quality assure assessment equivalency. Major challenges could be related to ownership of the degree and hence restrict following to the awarding degree policies and procedure may be invalid and a need for customization to fit with the context is required.

\subsection{Quality Assurance of the Collaborative Provision (Awarding and Certification)}

Studies were conducted in 2001 stating that the relationship between internationalization and quality assurance is lacking Van der Wende, M. C., \& Westerheijden, D. F. (2001) [30]. Since 2001, various studies were conducted which consist of recommendations to policy makers to include quality assurance mechanism for collaborative provision, thus maintaining equivalent level of delivery. According to Stella, A. (2006) [27] quality assurance for cross boarder qualification is important and emphasized on implementing UNESCOOECD developed Guidelines for Quality Provision in Cross - border Higher Education that could be used to address this issue, which is also in line with SDG4. Stella, A. (2006) [27] study concluded with recommendable actions and future directions related to International Network for Quality Assurance Agencies (INQAAHE). As stated previously that BQA Bahrain aligned its strategy to SDG4 and assured its implementation through various quality assurance frameworks and standards. This includes programme review standards that focus on implementing UNESCO-OECD Guidelines for Quality Provision in Cross - border Higher Education as well NQF alignment for collaborative provision qualifications. Furthermore, BQA members play an active role in ANQAHE by promoting Arab Qualification Framework Model (2012) [4].

As a case, an internal quality assurance was conducted by the hosting HEI to assure compliance with regulatory requirements as well as systematic external quality assurance audits. As a reflection of the implementation, the qualification was aligned to Bahrain NQF at level 10 for the PhD and level 9 for PG. The alignment validates the quality assurance and equivalency of standards.

The following table describes the adapted framework and highlights the challenges faced by the HEI while activating internationalization strategy. The table also states in summary the successful practices that could be adapted by HEIs while considering collaborative provision. 
Table 3. Analysis of adapted framework and practices

\begin{tabular}{|c|c|c|c|c|}
\hline $\begin{array}{c}\text { BQA Alignment } \\
\text { Standards } \\
\end{array}$ & $\begin{array}{c}\text { Internal } \\
\text { Framework }\end{array}$ & Challenges & $\begin{array}{l}\text { Intake } \\
\text { Level }\end{array}$ & Practice \\
\hline $\begin{array}{l}\text { Ownership of the } \\
\text { Qualification }\end{array}$ & $\begin{array}{l}\text { Admissions } \\
\text { requirements }\end{array}$ & Recognition of RPL & $\begin{array}{l}\mathrm{PhD} \\
\mathrm{PG}\end{array}$ & $\begin{array}{l}\text { - Admission Requirement is restricted to } \\
\text { regulatory standards in the hosting country (with } \\
\text { valid screening by the awarding HEI in } \\
\text { coordination with the delivering HEI) }\end{array}$ \\
\hline $\begin{array}{l}\text { Justification of } \\
\text { Need }\end{array}$ & $\begin{array}{l}\text { Academic Planning } \\
\text { Framework } \\
\text { (Resource Planning } \\
\text { and Delivery) }\end{array}$ & $\begin{array}{l}\text { Addressing the } \\
\text { Context to be fit for } \\
\text { purpose for the } \\
\text { market demands }\end{array}$ & $\begin{array}{c}\text { PG } \\
\mathrm{PhD} *\end{array}$ & $\begin{array}{l}\text { - Assessments are revised where necessary to } \\
\text { address the context need including market and } \\
\text { industrial case studies } \\
\text { External Verification and Moderation of } \\
\text { assessments are made by the awarding HEIs and } \\
\text { overseen by an independent external examiner } \\
\text { Faculty professional development to fit with the } \\
\text { context and compliance with awarding body * }\end{array}$ \\
\hline Quality Assurance & $\begin{array}{l}\text { Quality Assurance } \\
\text { of the collaborative } \\
\text { provision }\end{array}$ & $\begin{array}{l}\text { Maintaining } \\
\text { Equivalency }\end{array}$ & $\begin{array}{l}\mathrm{PhD} \\
\mathrm{PG}\end{array}$ & $\begin{array}{ll}- & \text { Implementation of UNESCO-OECD } \\
\text { - } & \text { Alignment with SGD } 4 \\
\text { NQF alignment to the national framework }\end{array}$ \\
\hline
\end{tabular}

\section{Conclusions and Recommendable Future Research}

HEIs are facing challenges in the sustaining of Internationalization strategies and maintaining active collaborative provision (Fleacă, E et.al 2018) [10]. Various studies were conducted and highlighted the need to consider internationalization strategies. This paper discussed private HEI practice in relation to Internationalization strategy and the importance of regulatory and quality assurance bodies in supporting HEIs to sustain collaborative provision.

This paper demonstrated a successful practice that enables the HEI to sustain its international collaboration and extended it for more since the year 2007. Regulatory and Quality Assurance agencies are playing a vital role in supporting HEIs to develop and sustain internationalization strategy. NQF alignment enabled validating the quality standards and the equivalency of the level of the awarded degree. Leadership plays also a vital role in sustaining internationalization strategies, it is important to select a similar partner with clear understanding between both parties. (Halik et.al 2019) [12].

HEIs must consider qualification alignment to NQF to validate their equivalency in terms of quality standards and delivery equivalency. HEIs are also recommended to conduct a comprehensive study prior to proceeding with the agreement; the study may include similarity of HEIs in terms strategic directions and integration of SDGs.

\section{REFERENCES}

[1] AACSB Standards 2020: https://www.aacsb.edu/-/media/aa $\mathrm{csb} /$ docs/accreditation/business/standards-and-tables/2020 $\%$ 20business \%20accreditation\%20standards.ashx?la=en\&h ash=E4B7D8348A6860B3AA9804567F02C68960281DA2

[2] Adel, H. M., Zeinhom, G. A., \& Mahrous, A. A. (2018).
Effective management of an internationalization strategy: A case study on Egyptian-British universities' partnerships. International Journal of Technology Management \& Sustainable Development, 17(2), 183-202.

[3] Aldhaen, Esra, Aravopoulou, Eleni and Stone, Merlin (2018) The role of qualification frameworks in assuring appropriate selection of assessment methods for quality learning. International Journal of Higher Education Management (IJHEM), 4 (2). pp. 24-33. ISSN 2054-9849 DOI: https://doi.org/10.24052/IJHEM/V04N02/ART02

[4] Arab Netweork for Quality Assurance Higher Education. "Qualification Framework ANQAHE Model." 2012. http://www.anqahe.org/uploads/7/3/3/4/73345067/anqahe_a qf_.pdf

[5] BQA Website: https://www.bqa.gov.bh//En/AboutQaaet/Pa ges/default.aspx

[6] Bahrain Education and Training Annual Report (2019) https://www.bqa.gov.bh/En/Publications/AnnualReports/A NNUAL\%20REPORT\%202019\%20ENGLISH_compresse d\%20(1).pdf

[7] Chalmers, D., \& Gardiner, D. (2015). An evaluation framework for identifying the effectiveness and impact of academic teacher development programmes. Studies in Educational Evaluation, 46, 81-91.

[8] Décamps, A., Barbat, G., Carteron, J. C., Hands, V., \& Parkes, C. (2017). Sulitest: A collaborative initiative to support and assess sustainability literacy in higher education. The International Journal of Management Education, 15(2), 138-152.

[9] Dunn, C. (2018). Challenges and opportunities for RPL in Open and Distance Learning: Lessons learnt from the Open University UK. Blended and Online Learning, 59.

[10] Fleacă, E., Fleacă, B., \& Maiduc, S. (2018). Aligning strategy with sustainable development goals (SDGs): Process scoping diagram for entrepreneurial higher education institutions (HEIs). Sustainability, 10(4), 1032.

[11] Foskett, N. (2010). Global markets, national challenges, local strategies: The strategic challenge of internationalization. Globalization and internationalization in higher education: Theoretical, strategic and management 
perspectives, $35-50$

[12] Halik, A., Hanafie Das, S. W., Dangnga, M. S., Rady, M., Aswad, M., \& Nasir, M. (2019). Empowerment of School Committee in Improving Education Service Quality at Public Primary School in Parepare City. Universal Journal of Educational Research, 7(9), 1956-1963.

[13] Henderson, M., Barnett, R., \& Barrett, H. (2017). New developments in transnational education and the challenges for higher education professional staff. Perspectives: Policy and Practice in Higher Education, 21(1), 11-19.

[14] Hornblow, D., Hasan, J., \& Morris, I. (2019). Recognition of Bahrain's National Qualifications Framework in the wider world.

[15] Jackson, N. (1997). Academic regulation in UK higher education: part I - the concept of collaborative regulation. Quality Assurance in Education.

[16] Karagoz, S. (2018). Sadrettin Celal Antel's Ten-Year Ministry Development Report: An Assessment Based on the Divisions of Educational Sciences. Universal Journal of Educational Research, 6(5), 1119-1128.

[17] Mehrotra, S. (2020). The National Skills Qualification Framework in India: The Promise and the Reality.

[18] Moldovan, L. (2020). A Reference Framework for Continuous Improvement of Employability Assessment. Procedia Manufacturing, 46, 271-278.

[19] National Qualifications Framework for the Emirates Handbook, National Qualifications Authority (NQA) https://www.nqa.gov.ae/EN/Pages/QFEmirates/Qualificatio nsFramework/Handbook.aspx

[20] Oanda, I. (2020). Admissions Policies and Practices and the Reshaping of Access Patterns to Higher Education in Africa. Higher Education Admission Practices: An International Perspective, 123.

[21] Oman Qualification Framework http://www.oaaa.gov.om/J ournal/Qualification\%20Arrangements.pdf
[22] Ong, K. C., \& Chan, D. K. (2012). Transnational higher education and challenges for university governance in China. Higher Education Policy, 25(2), 151-170.

[23] Programmes-within-Review Handbook (Academic) (2019), Cycle 2 Handbook, Bahrain Education and Training Quality Authority (BQA)-https://www.bqa.gov.bh/En/Publications/ DocLib/1.\%20APRs\%20Handbook\%20-\%20English\%20V ersion $\% 2027 \% 20$ October\%202019.pdf

[24] QS World Ranking, https://www.topuniversities.com/unive rsity-rankings

[25] Shaukat, S., Vishnumolakala, V. R., \& Alghamdi, A. K. H. (2020). Science Teachers' Perceptions of Personal Science Efficacy Beliefs and Science Teaching in Saudi Arabia, Pakistan, and the United Arab Emirates. EURASIA Journal of Mathematics, Science and Technology Education, 16(8), em1866.

[26] Shyamasundar, M. S. Assuring the Quality of Collaborative Provision of Transnational Higher Education.

[27] Stella, A. (2006). Quality assurance of cross - border higher education. Quality in Higher Education, 12(3), 257-276.

[28] Tamronglak, A. (2020). Impacts of the Thailand qualification framework-Public administration on public administration education in Thailand.

[29] Take, H., \& Shoraku, A. (2018). Universities' expectations for study-abroad programs fostering internationalization: Educational policies. Journal of Studies in International Education, 22(1), 37-52.

[30] Van der Wende, M. C., \& Westerheijden, D. F. (2001) International aspects of quality assurance with a special focus on European higher education. Quality in higher education, 7(3), 233-245.

[31] Wiek, A., Withycombe, L., \& Redman, C. L. (2011). Key competencies in sustainability: a reference framework for academic program development. Sustainability science, 6(2), 203-218. 